\title{
Media responses to US Corporate and Global Environmentalist Projects in Amazônia, 1928-2000
}

\author{
Reportagens na mídia sobre empresas EEUU \\ e Projetos Globais Ambientais na Amazônia, 1928-2000
}

DANIEL ZIRKER*

\section{INTRODUCTION}

Few other countries, if any, have struggled so long, and so effectively, to secure and develop such a vast part of their national patrimonies as has Brazil and its Amazônia, (BA). Central to designs on Brazil's national sovereignty have been the news media. Two distinctive sets of media have been influential in this regard, and have struggled between themselves to gain a dominant and persuasive monologue: the Brazilian and Iberian media, on the one hand, and the US and Western media, best exemplified by the New Tork Times (NYT), on the other. Three terms in English, each with its separate policy implications, have dominated media reporting in this regard: reference to the BA as a "Brazilian wilderness" (according respect for Brazilian national sovereignty over the $\mathrm{BA}$ ); reference to the BA as a "frontier," implying that the BA is "hollow," unclaimed territory, justly claimed by an effective power; and reference to the BA as the hopeless victim of environmental and human rights mismanagement, implying the right to "internationalize" the region, attenuating or even disestablishing Brazilian national sovereignty over the region. The often subliminal character of these three distinctive emphases came to dominate both the thinking and policy making in three eras, before 1926; 1926-1982; and 1982-2000 (and beyond).

Prior to the 19th century, competing metropoles, France, Holland,

\footnotetext{
* Professor of Political Science, including supervision of undergraduates and graduate students, research and publication in University of Waikato. Contact: dzirker@waikato.ac.nz.
} 
England, Spain and Portugal, routinely engaged in repeated "discovery" and seizure of lands in the Americas, including in Amazônia. This represented a presumption of the right to seize (or at least occupy) what was generally regarded as a "hollow frontier," and easily metamorphosed into presumed international rights to interfere with national sovereignty in the 2oth century under the guise of acquiring "vacant" lands and, later, the protection of the global environment and internationally-defined human rights. The international media played a major role after 1926, particularly in their characterization of the BA as a "frontier" (in English), rather than as a "Brazilian wilderness," a subtle change in language that had farreaching implications. After 1985 the Brazilian media directly addressed tacit threats to national sovereignty in the BA, and gradually assumed a leading voice in the dialogue.

The US Central Intelligence Agency (CIA) kept track of foreign media reports of interest through their Foreign Broadcast Information Service (FBIS), which translated selected articles in the international press into English, at first for CIA usage only, and later made available to researchers. Perhaps the most dramatic change in language and attitude of the domestic and international press came in the mid-1980s, when the Brazilian army established Calha Norte, a subject of obvious relevance to the CIA considering the number of FBIS translations on this subject. At about this time, the Brazilian military began widespread operations in northern Brazil and the Brazilian media began to confront the question of national sovereignty as it related to threats of the "internationalization" of Amazônia. This signalled the beginning of fifteen years of political tensions, particularly evident in contrasting North American and European versus Brazilian media accounts of Amazônia.

\section{THE ENGLISH LANGUAGE CONCEPT OF "FRONTIER"}

Geographical interpretations in English of the AB have long stressed its status as a frontier, ' and even a "hollow frontier" (Rausch 2008), seen as a central influence in shaping the status of the BA vis-à-vis European and North American countries. Use of the term frontier in effect denigrated the BA's status as an implicit part of Brazil's national patrimony, tacitly characterizing it as an "unsettled" and thus not a fully claimed area, little more than a locus for Brazil's future territorial expansion. Mary Lombardi argued in the 1970s that "territorial expansion is a major theme [in Brazil]” (1975, 438), although she admits that comparisons of Brazil with 
the frontier expansion, literally "the claiming of unclaimed territory," in North America, for example, are problematic. "Such statements, whether about the significance of the frontier in Brazilian history or in Latin American history generally, are not always in agreement or supported by evidence" (438-9), adding that

Settlement in the Amazon region has been sporadic at best. The rubber boom of the late nineteenth century found increased national and international attention focused on the area, but after its "bust," the region returned to its former role of obscurity and neglect, leaving behind, of course, the "hollow frontiers" which have characterized so much of the development of Brazil's sertão. In [the twentieth] century, the Amazon may finally be in the process of effective settlement as a result of the completion of the trans-Amazon highway. If so, however, such a development will mark a dramatic break with past tradition...

$(456-7)$.

The description of the BA as "unsettled" carries with it a tacit rejection of Brazilian national sovereignty. "Frontier," in its English language usage, suggests that the BA is not fully Brazilian territory, aerial mapping, aerial surveillance, and rapid troop deployment to the contrary notwithstanding. As Hecht and Cockburn noted in 1990, "Amazônia was seen as empty, and easily annexed economically, ideologically, and perhaps even territorially" (1990). Stephen Bunker added in his 1985 work that that there were several reasons why "the notion of frontier must be carefully qualified when it is used in the Amazon..."(Bunker: 99). Bunker argued that it had been the foreign extraction of resources, first Brazil nuts and spices, later rubber and then minerals, from the Amazon that had ultimately shaped that region's uniquely "vulnerable" status (1985). From this perspective, application of the English word frontier to the BA seems more like a rationale for foreign and centre- state appropriation of resources, than a useful description of an immense and diverse region, thoroughly mapped (from the air), militarily encircled by a buffer zone (Calha Norte), and continually surveyed by a complex air surveillance and air traffic control system, the SIVAM. Even in the late 1990s, use of the English word "frontier" regarding the BA did not seem to refer to Brazilian borders, however; rather, the references almost always referred to "unclaimed" or even "mismanaged" (and therefore "undeserved") territory.

In the 1990s, when international human rights and environmental organizations intensified their campaigns to limit Brazilian development efforts in the BA, this concept of a "hollow frontier," and its implication of "unclaimed land," was even further emphasized. The "mishandling" of the 
environment of the BA was a constant refrain in the 1990s, although by 1990, "more than 40 percent of Amazônia [was] in some kind of conservation designation, and of [this], some 80 million hectares (60 percent) [were] protected as inhabited landscapes and [were] the framework for reimagining tropical development in the context of both neoliberal and neo-environmental frontiers" (Hecht and Cockburn 1990). Then-Senator Al Gore had declared famously in 1989, however, that "contrary to what Brazilians think, the Amazon is not their property, it belongs to all of us" (quoted in the NYT, 19 May 2008).

The NYT persisted in referring to the BA with the English word "frontier" well into the 1990s. By the 2000s, however, when Brazil's BRICS status and rapid economic development finally established it as a Great Power, reporting in English on the Amazon began to change, and the BA once again came to be referred to in the NYT as a "Brazilian wilderness" rather than a "frontier." Media allegations over the alleged mishandling of the BA by the Brazilian government were rare, and Brazil was apparently finally accorded, by the NYT at least, its status as national sovereign over a territory that had been fully demarcated and incorporated into it for more than a century.

\section{RUBBER, WILDERNESS, AND BORDERS}

While Brazilian consolidation of the BA languished during the first half of the 19th century, the scramble for expropriation of BA resources after 1850 was unparalleled, and revolved around a rapidly growing global hunger for rubber, a product available at the time only in the Amazon in native plants, the most productive of which was the Hevea brasiliensis. The rapid growth in the harvesting, refining and export of this product of the Amazon forest is described as one of the greatest of Brazil's many "booms," and one that was ended, like the much earlier sugar boom, by the European theft of its object, Hevea brasiliensis. While difficult to grow commercially in the Amazon because of diseases and parasites, it turned out to be well suited to commercial production in Southeast Asia. It is significant that the most important description of the BA in the Englishspeaking media of this era was as the "Brazilian Wilderness."

The unique border stabilisation policies of the Barão do Rio Branco, José Maria da Silva Paranhos, Jr., Foreign Minister between 1902 and 1912, is unique in modern diplomatic history. Bunker notes, however, that Brazilian economic elites were often more than willing to allow foreign 
interests great political and economic interests in exchange for anticipated (but rarely received) personal benefits in this "Brazilian wilderness." The respect shown for Brazilian national sovereignty over the BA changed dramatically by the 20th century. In 1914, for example, former President Theodore Roosevelt accepted the invitation of Brazilian Foreign Minister Lauro Müller to explore the uncharted Rio de Dúvidas (Roosevelt, 1914: 5). Roosevelt was a strong supporter of military preparedness and national sovereignty as principles, and was fully supportive of Brazil's ownership of the Amazon region. His trip through the "Brazilian Wilderness" (Roosevelt, 1914), on which he was accompanied by the then-Colonel Cândido Rondon, met with strong approval from the Brazilian government. The river that he explored was renamed the Rio Roosevelt (Millard, 2006; Roosevelt, 1914). Roosevelt continually affirmed his belief in the rights of national sovereignty, and military preparedness (of all countries), a philosophical, if uneven, product of the nineteenth century US that led to his striking and hostile debate with a major US industrialist at the time, Henry Ford, a strident pacifist and globalist. Ford opposed WWI, disparaged military preparedness in the strongest terms (although he profited from it), and evinced a concerted disregard for the concept of national sovereignty. Moreover, he was already eyeing the Amazon as a key source of rubber, vital to his industrial process.

In 1926, after extensive consultation with rubber manufacturer Harvey Firestone, Ford purchased land from the Brazilian government on the Tapajós River, described in the NYT as the size of the state of Connecticut (Grandin 2009, 3). From the first, Ford characterized his venture to the media as the internationalizing and "industrializing" the BA (Grandin, 2009:5), and as a battle against a harsh environment, launching what his son Edsel called a "widespread sanitary campaign against the dangers of the jungle” (quoted in Grandin 2009, 3). The NYT initially reported Ford's diplomatic and conciliatory comments regarding Brazil and Brazilians in the region. In 1928, in a NYT article, Ford was reported to have declared that "manufacture of finished products from Brazilian rubber should be located in Brazil. It is due that country that we keep as much of the industry growing out of the [Fordlândia] plantation as we can in the country itself" (16 November 1928). Within two years, however, the NYT was criticizing the city of Santarém because the city officials and state governor had not accorded financial incentives to Ford's project, and hence had lost a golden opportunity (2 March 1930). 


\section{PURCHASING "FORDLÂNDIA" AND BRAZIL'S NATIONAL SOVEREIGNTY}

The purchase of Fordlândia apparently took place with little notice at first from the NYT. Ford had been approached by Brazil's consular inspector in the US, José Custódio Alves de Lima, after reading about Ford's failed plan to grow rubber in the Florida Everglades. Alves de Lima pressed Ford on the possibility of buying land in the BA. Ford at the time had produced 60 percent of the cars sold in Brazil (Gransin 2009, 78). Although the new Vargas government was reported in the US press to have immediately challenged the Ford concession, and especially its attempts to evict "squatters" from purchased lands (NYT 27 Dec. 1930), there was little news of Fordlândia during its first five years. The NYT reported in an article in 1931 significant "opposition to Ford," primarily because the estate had been purchased during the Washington Luis presidency and lacked support under the new Vargas regime. Vargas soon came to terms with Ford, and made at least two well-publicized trips to Fordlândia, in 1933 (NY Times, 28 September 1933), and in 1940 (NY Times 22 October 1940), using the second trip to publicize his own plans to develop the region. Henry and Edsel Ford never visited Fordlândia, despite their penchant for micro-managing the project.

Getúlio Vargas soon replaced the state governor of Pará, and Brazilian acceptance of Fordlândia increased. Ford soon had 1,300 men on his payroll, and was paying his Brazilian employees the equivalent of only 30 US cents per day. He bragged that he had closed down the "gambling dens" and prevented the sale of alcohol, and was said to have constructed a "model" US city, "completely free from the deadly mosquitos [sic $]$ which swarm the Amazon region", with schools and compulsory education for the children of all workers. The main city was said to be a model Midwestern US town, a moral and decent place, free from the vices and the diseases of the BA. Moreover, the "Ford Estates" were reported in the US press to be earning huge sums for the government of Pará, with $\$ 1.4$ million in construction supplies purchased in Belém in the previous year (NYT 3 May 1931).

Fordlândia was far from the image that Ford had projected in the US press. The struggles to find adequate sources of labour, and Brazilians' angry rejection of Ford's plan to import US "negro" workers, as per an editorial in the Estado de São Paulo (trans in the NYT 9 June 1929), were 
intensified by Ford's insistence that gambling and prostitution be curbed, and that workers be monitored closely for their "moral aptitude." Despite Ford's insistence on micro-managing the Brazilian labour force, management in Fordlândia tended to be poor, and plantation managers tended to be inadequate, sometimes wasting millions of dollars to save a few dollars. Additionally, Ford's agricultural research on the commercial planting of rubber trees in the BA was virtually non-existent. The significant distances between wild rubber trees in the Amazon had an evolutionary basis, it turned out. The infections caused by the many diseases and parasites that afflicted the trees were mitigated in the wild by the natural distances between them. In Southeast Asia, these diseases and parasites did not exist, and hence dense planting was commercially viable.

Fordlândia ultimately failed because of two factors: first, poor management; and second, the dense planting of Hevea brasiliensis, which simply did not work in Brazil. The NYT, however, in a terse, one-column article, reported the failure of Fordlândia in 1945 as the direct result of Brazilian labour laws, noting dryly that Ford ultimately gave the $\$ 15$ million facilities and lands to the Brazilian government because of Brazilian labour problems (29 November 1945). The US press came to adopt the Brazilian labour problems as the sole cause of the failure of Fordlândia, yet another, if oblique, attack on Brazil's management of the region, and thus on its national sovereignty.

Only four years after Fordlândia's collapse, in a NY Times article by Canadian-American journalist Willard Price, later identified as a spy for the US government, an international agenda for the BA was laid out: "The next hundred years might quite possibly see the transformation of the Amazon basin, one of the largest of earth's "empty spaces," into a vast tropical granary and a home for millions of people from overcrowded lands. Such an eventuality would have far-reaching effects on the social and economic future of mankind" (Price 1949). The "internationalization" of the region, importation of overflow populations and extensive food production for them, was thus introduced. In the 1990s, Brazilian generals were accused of paranoia when they referred to Western plans to relocate excess Asian populations to the BA; ${ }^{3}$ however, the NYT had already introduced this idea, as Price's article indicated.

\section{TRANSAMAZÔNICA TO JARÍ}

From the collapse of Fordlândia in 1945, to the military coup in Brazil in 
1964, the BA largely disappeared from foreign media accounts, and the competing dialogue regarding Brazil's national sovereignty over the region was, in effect, suspended. With the exception of articles like that of Price, and occasional travel and adventure accounts, the NYT seems to have lost track of the BA. When the BA re-emerged in occasional articles in the late 1960s, it was as the focus of massive development projects sponsored by the military, principally the TransAmazônica, road building and migration into the BA, and the Superintendência do Desenvolvimento da Amazônia (SUDAM), regional research and development. By this time the $F B I S$ was identifying and translating into English what the CIA regarded as important articles in the "foreign" press, including from the Brazilian media (newspapers and radio), and these provide crucial insights (by their selection for translation) into US concerns in the BA.

The purchase for $\$ 3$ million of 16,000 square kilometres of the BA in 1967 by US millionaire Daniel Ludwig, later described as the "largest private landholding in Brazil, and perhaps in the Americas” (Kandell 1976), was one of the largest sales of Brazilian national territory to foreign interests in history. The Jarí reserve on the lower Amazon represented an acceleration of the internationalist aspect of the Brazilian military dictatorship's developmentalism. This differed markedly from earlier acquisitions in one key respect: despite military support, Brazilian politicians and even Brazilian newspapers criticized this massive foreign land holding, and the Brazilian media began to exercise a major influence on global opinion in this regard. According to the Jornal do Brasil (30 November 1975, 4, trans. FBIS), Senator Evandro Carreira (MDB-AM) affirmed that this was the first step in a much broader internationalization of the region, with "U.S. and Salvadoran companies [trying] to purchase large areas of land in Amazonas to build towns designed to shelter people from overpopulated areas, mainly South Vietnamese". ${ }^{5}$ Global attention was now turned by the media on Brazil, moreover, and its own alleged "expansionist" motives behind its efforts to gain an Amazon regional cooperation treaty, with charges reported in Colombia of "Brazilian cultural expansionism" (El Siglo [Bogota], 7 September 1977, 5, trans FBIS). The English-language Buenos Aires Herald was quick to report the "failure" of the Amazon pact because of Venezuela's fears of Brazilian expansionism (19 December 1977, 9, FBIS file), although Brazil was later successful in this treaty.

By 1979, the Brazilian Chamber of Deputies was reported to be investigating the Jarí project, primarily because Ludwig's will had reportedly left the entire Jarí landholdings to the US government (Latin [Buenos Aires], 
6 April 1979, trans. FBIS). By November of 1980, the Brazilian Mines and energy Ministry turned back Ludwig's attempted sale of a large bauxite deposit on "his land" to US Alcoa Corporation $(A F P$ [Paris] 18 November 1980, trans. $F B I S)$. In 1982 an English language paper in Brazil reported that "the salvation of the most ambitious project ever undertaken in the Amazon region is currently being worked out in the back corridors of power in Brasília and the boardrooms of some of Brazil's most prestigious financial and industrial concerns" (Latin American Daily Post $[$ Rio de Janeiro], 12 January 1982, FBIS file). Less than one month later the same paper reported the complete transfer of the $\$ 1.1$ billion project to a Brazilian government-sponsored consortium (Latin American Daily Post 27 January 1982, FBIS file). Today the remains of the project are in Brazilian hands, with some elements of the diversified holdings still producing limited returns.

\section{ENVIRONMENT AND HUMAN RIGHTS: CALLS FOR INTERNATIONALIZATION}

By the 1990s, the Brazilian media had begun protesting increasing pressures to "internationalize" the BA based on claims of human rights violations and destruction of the BA environment, the "lungs of the earth," as some referred to it. A lengthy report in the magazine Istoé in 1994 noted that "forest burning, mineral smuggling, the massacres of Yanomami, the activities of drug traffickers and landings on clandestine airstrips have all contributed to reinforce the image of a territory that is almost abandoned" (2 March 1994, 62, trans FBIS). The “orthodox" Brazilian military mission in the region, however, defending the borders and protection of a significant national patrimony, was difficult to refute. By 1991 the Folha de São Paulo was reporting Brazilian military plans to turn the BA into another Vietnam were it to be invaded by the United States, ${ }^{6}$ a scenario that had seemed to be extremely unlikely only a few years earlier. Several other concerns seemed to coalesce in the military's regional policymaking. First, the regional development policies of the 1970s, most notably TransAmazônica and SUDAM, were still unfolding. Second, the lengthy and largely undefended international borders in the region were increasingly threatened by nonstate actors, resulting in the creation of Calha Norte, said by 1990 to give priority to "preserving the forest" (O Globo 22 March 1990). The tenders for an Amazon radar system, SIVAM, were issued, and the project was eventually awarded to a US company, Raytheon, amidst scandal and controversy. 
Third, by 1990 the newly elected president, Fernando Collor de Mello, had broken with the military over the intelligence system, and was moving to emphasize environmentalism, appointing José Lutzenberger as Minister of the Environment, and establishing Indian reserves (the Yanomami reserve ran into Venezuela) in advance of the first UN Conference on Sustainable Development, held in Rio de Janeiro in 1992. The military regarded the reserves as potential quasi-nations, and hence as an international confiscation of Brazilian national territory. Fourth, senior military officers feared that Brazil's huge international debt would be used by the US and European countries (particularly Germany) to alienate Brazilian rights and privileges in the BA. Collor de Mello's appointment of Lutzenberger, whom senior military officers regarded as akin to a communist, irritated them. Meanwhile, agents of Western countries, principally the United States, were reported to be engaged in anti-environmental activities in the region, including smuggling precious woods (Rede Globo $T V 2$ February 94, FBIS file), rare tropical fish (Folha de S. Paulo 10 February 1994, Section 3, p. 4), and minerals. The government of Roraima had only one year earlier blamed its problems with the local Indians on the illegal presence of "foreign" (read: "US") interests (Folha de S. Paulo 20 August 1993, 11).

Meanwhile, the US military repeatedly requested that the Brazilian army cooperate in joint military manoeuvres in the BA. The US was engaging in manoeuvres with Colombia, Venezuela and Guyana, leading Navy Minister Admiral Mario César Flores to conclude that there were early indications of a possible foreign (US) military intervention in the BA ( $O$ Globo 9 October 1991, 8). Later, US military manoeuvres with Guyana led to a Brazilian military mobilization near the Guyana borders (Estado de S. Paulo 13 August $1993,4)$. By the late 1990s, military irritation with US policies had reached a feverish pitch, with a regional commander refusing US water bomber assistance during major fires in Amazônia, and a brigadier who was not bound by regulamento disciplinar (RDI) declaring that Brazil's likely global enemy was the United States (Ferolla 1998, 25). Although a visit to Brazil by the commander of SOUTHCOM (the US Southern Military Command) was said by the Brazilian media to have cooled tensions considerably (Correio Brasiliense 17 March 1994, trans FBIS), a review of Brazilian media accounts at the time suggest that they played a crucial role, primarily in their consistent and outright rejection of the BA as a "hollow frontier," and in their continual rejection of the country's alleged human rights and environmental violations. 


\section{CONCLUSIONS}

North American and European media characterised the BA after 1920 as an "empty frontier," a vital and uninhabited world ecology site, or as a natural history museum that was abused and required international regulation and management. Beginning in the 1920s, world industrial designs on the natural resources of Asia, Africa and Latin America accelerated significantly. Vast fortunes depended upon the appropriation of resources, be it through sale or intervention. Little has apparently changed in this regard. Use of the English word "frontier" to apply to perceived natural resources production areas and ecological treasures continues. The 1920s, in some respects the birth of globalism, was a new historical era, and reports of the BA in the NYT, for example, clearly reflected it. The BA is unique, however. Its scale is almost incomprehensible, its potential impact on world resources and climate incalculable, and even though Brazil has become a world power, that status has repeatedly been challenged by Western countries hungry for resources in an ever declining global economy. In a 2011 report the NYT noted in alarm the killing in the state of Pará of a rural environmental activist and his wife, linking the incident to other evidence of "mismanagement" of the region (Rudolf 2011). More recently, the NYT reported that although environmental destruction of the Amazon had largely subsided, ${ }^{7}$ the government of Dilma Rousseff was now poised to initiate a wholesale destruction of the forest: "What is happening in Brazil is the biggest backsliding that we could ever imagine with regards to environmental policies," former Green Party candidate for the presidency Marina Silva is quoted as saying. The article chooses to emphasize Silva's message, that the government of Brazil may be politically incapable of protecting the ecology of this vital "international" resource (NY Times 24 January 2012). Brazil, it is implied, only has national sovereignty rights over this region if it acts according to a set of externally-defined standards.

The BA, however, has proven repeatedly to have the power, through its richness, isolation and vastness, to write its own history, and to play a vital and unscripted part in the history of Brazil. ${ }^{8}$ It is easy to conclude that the vast green expanse needs no international fiduciary, that it is a primordial power in its own right, that it will ultimately determine the fate of countries, and not vice versa. As Euclides da Cunha wrote in the 1920 preface to Alberto Rangel's classic work on Amazônia, Inferno Verde, "realmente, a Amazônia é a ultima página, ainda a escrever-se, do Genesis" (Rangel 1920, 9). 


\section{NOTES}

1. In Portuguese, the term "fronteira" is far more limited, suggesting borders and land near borders.

2. This was an extremely questionable claim, shown to be little more than an empty boast in retrospect.

3. In an interview in August of 1991, General Thaumaturgo Sotero Vaz, military commander of the Amazon region, noted repeated foreign attempts to occupy the BA, and noted that "we are not going to allow UN-sponsored projects to transfer excess population from Asia to the Amazon region" (Folha de S. Paulo 28 August 1991, 9, trans FBIS).

4. The author accessed the FBIS files in the US Library of Congress in May, 2013.

5. It continued: "According to Carreira, during a recent seminar...Roraima Territorial Governor Col. Fernando Ramos Pereira was approached by a highranking U.S. Army officer, who in the name of a U.S. company, proposed the purchase of an area to build a city for 100,000 persons, presumably South Vietnamese." Also mentioned in Carreira's comments was his receipt of "official information" regarding a Salvadoran company's proposal to buy a large tract of land to re-settle excess Salvadoran population.

6. In a Folha de S. Paulo report, "General Antenor de Santa Cruz Abreu, chief of the Military Command of the Amazon, has said that the Brazilian Army 'will transform the Amazon into a new Vietnam' if developed countries adopt a concrete attitude on internationalization of the region....A document issued in 1990 by the War College (ESG) talks about the possibility of Brazil resorting to war against an internationalization of the Amazon....Irapuan Costa Junior, PMDB...senator for Goiás, said Abreu's statement 'was a reaction against the avarice of rich countries toward the Amazon"" (Folha de São Paulo 23 July 1991, 1, trans FBIS).

7. "The rate of deforestation fell by 80 percent over the past six years, as the government carved out about 150 million acres for conservation - an area roughly the size of France - and used police raids and other tactics to crack down on illegal deforesters, according to both environmentalists and the government." (NY Times 24 January 2012).

8. Euclides da Cunha wrote in 1920 that “...na Amazônia, as mudanças extraordinárias e visíveis resaltam no simples jogo das forças físicas mais comuns. É a terra moça, a terra infantil, a terra em ser, a terra que ainda está crescendo..." (Rangel 1920, 10). 


\section{RESUMO}

Interesses militares, ambientalistas e corporativos dos EUA e da Europa forão fixados na Amazônia desde 1926. Analisa tentativas em estabelecer extração de recursos na Amazônia, crises entre os militares estadounidenses e brasileiros, e a mídia sobre resistência aos projetos corporativos e ambientalista na Amazônia até o final da década de 1990.

Palavras-chave: Projetos na Amazônia. América. Mídia. Extração de recursos. Militar brasileiro.

\section{ABSTRACT}

Military, environmental and corporate US and European interests were focused on Amazônia after 1926. This analyzes attempts to extract resources, US-Brazilian military crises, and the media on resistance to corporate and environmental projects in Amazônia up to the end of the 1990s.

Keywords: Projects in Amazônia. America. Media. Resources extraction. Brazilian's military.

\section{REFERÊNCIAS}

Bunker, Stephen G. 1985. Underdeveloping the Amazon. Chicago: University of Chicago Press.

Ferolla, Sérgio. 1998. “O Brigadeiro Sérgio Xavier Ferolla, military quarto-estrelas da ativa, critica o governo, aponta os Estados Unidos como inimigo e defende a soberania nacional, na entrevista explosive." Caros Amigos, No. 20 (November): 22-27.

Grandin, Greg. 2009. Fordlandia: The Rise and Fall of Henry Ford's Forgotten Jungle City. New York: Picador.

Hecht, Susanna and Alexander Cockburn. 1990. The Fate of the Forest: Developers, Destroyers, and Defenders of the Amazon. Chicago: University of Chicago Press. 
Kandell, Jonathan. 1976. "The Expanding Empire of a Quiet Tycoon.” NYT (May 2).

Lombardi, Mary. 1975. "The Frontier in Brazilian History: An Historiographical Essay." Pacific Historical Review, 44, No. 4 (November): 437-457.

Millard, Candice. 2006. The River of Doubt: Theodore Roosevelt's Darkest Journey. New York: Anchor Books.

O'Connor, Geoffrey. 1997. Amazon Journal: Dispatches from a Vanishing Frontier. New York: Plume, Penguin.

Price, Willard. 1949. "Amazonia-A Granary Out of the Jungle: The Brazilian Wilderness May Some Day Be One of Mankind's Richest Treasure Houses.” NYT (July 31).

Rabben, Linda. 1990. "Brazil’s Military Stakes Its Claim; Amazon Gold Rush." The Nation, 250, Issue 10 (March 12): 341-2.

Rangel, Alberto. 1920. Inferno Verde (Scenas e Scenarios do Amazonas). Prefacio de Euclides da Cunha. Tours: Typographia E. Arrault.

Rausch, Jane M. 2008. "Frontier Theory as an Explanatory Tool for Brazilian History: A Viable Construct." Latin American Research Review, 43, No. 1: 201-207.

Roosevelt, Theodore. 1914. Through the Brazilian Wilderness. New York: C. Scribner's Sons.

Rudolf, John Collins. 2011. "Murder of Activists Raises Questions of Justice in Amazon.” NrT (May 28). 